\title{
Optimization of Malting and Mashing Conditions of Sweet Sorghum Grains as a Brewing Source
}

\author{
Seema Mesta, G.S. Geeta* and M. Ashwini \\ AICRP on EAAI (Bioconversion Technology) \\ University of Agricultural Sciences, Dharwad - 580 005, India \\ *Corresponding author
}

\section{A B S T R A C T}

Keywords

Malting, Amylase activity, Reducing sugars, Commercial enzymes,

Hydrolysis, Wort

Article Info

Accepted:

06 June 2018

Available Online:

10 July 2018
Sweet sorghum grains have high starch content which can be converted to sugars by malting and mashing processes. Three sweet sorghum cultivars 'SSV-74', 'SSV-84' and 'SSV-108' and a sorghum cultivar 'SSV-2' were screened for their amylase activity and reducing sugars. Grains were soaked at three different time intervals of $8 \mathrm{~h}, 12 \mathrm{~h}$ and $16 \mathrm{~h}$ and germinated subsequently for 2 and 3 days. The highest amylase activity $(1266.10 \mu \mathrm{g}$ of protein $/ 15 \mathrm{~min} / \mathrm{g}$ of sample) was recorded in sweet sorghum cultivar 'SSV-84' soaked for a time interval of $16 \mathrm{~h}$ and germinated for 3 days. Similarly, 'SSV-84' recorded the highest reducing sugars $(33.85 \mathrm{mg} / \mathrm{g})$ at a soaking time of $16 \mathrm{~h}$ and a germination period of 3 days. Commercial $\alpha$-amylase (Palkozyme) was used at different concentrations of 0.1 , 0.5 and 1 per cent at different incubation temperature and incubation period for release of maximum reducing sugars. The highest reducing sugars $(78.83 \mathrm{mg} / \mathrm{g})$ was recorded in variety 'SSV-84)' at an enzyme concentration of 1 per cent at $70^{\circ} \mathrm{C}$ for an incubation period of $24 \mathrm{~h}$.

\section{Introduction}

The name "Sweet sorghum" is used to identify varieties of sorghum (Sorghum bicolour (L.) Moench) those are sweet and juicy. These sweet stalk varieties are currently grown for sugar production, forage and silage. White sugar and jaggery was produced from it in India in 1975 (Bhise et al., 1988). Sweet sorghum has become a leading contender in biomass production for energy systems because of its high yield, per cent of fermentable sugars and its adaptability to drought areas. It could produce 50 metric tonnes of crushable stalks, 3 metric tonnes of grains and 17 metric tonnes of leaves and stem tops per hectare (Almodares et al., 1994). Its rapid growth and ability to reach maturity in 3 and 5 months, when coupled with its lack of photoperiodism are favourable for its production on fallow sugarcane land, primarily because it can be grown, and harvested before the start of the sugarcane harvesting season. Sweet sorghum stalks, containing high sugars have been readily exploited for fuel ethanol. Furthermore, sweet 
sorghum is rich in micronutrients and minerals (Seetharama et al., 2002). The grains on the other hand are rich source of carbohydrates which can be converted into sugars by the action of endogenous enzymes activated during sprouting. The grains of sweet sorghum are rich source of carbohydrates which can be converted into sugars by the action of endogenous enzymes activated during sprouting. This could be further diverted towards beer production. Rothschild (1972) used plain sorghum, sprouted sorghum and maize grits for the production of Bantu beer in South Africa and obtained ten million litres of beer during the first month of operation. Satyanarayana and Narasimham (1975) advocated the use of 40 per cent sorghum as an adjunct in brewing and concluded that it compared very favourably with beer made from 100 per cent malted barley. Also, in the tropical countries, barley has to be imported from other temperate countries and this involves expenditure of scarce foreign exchange. Besides, sweet sorghum also requires minimum fertilizer inputs than barley. Hence, sweet sorghum could be a new potential substitute for barley and could raise economic benefits. Thus, the present investigation lies in optimising different parameters of malting and mashing of sweet sorghum grains.

\section{Materials and Methods}

The sweet sorghum varieties selected for beer production were 'SSV-74', 'SSV-84' and 'SSV-108' and a sorghum variety 'DSV-2' which were procured from AICRP on sorghum, UAS, Dharwad.

The grains, were soaked at different time interval of $8 \mathrm{~h}, 12 \mathrm{~h}$ and $15 \mathrm{~h}$ in normal tap water and subsequently germinated at two different periods of 2 days and 3 days in clean muslin cloth. Amylase activity and reducing sugars were determined. The malt was kilned at $50^{\circ} \mathrm{C}$ in hot air oven for $24 \mathrm{~h}$. The kilned grains were further broken into grits by running through a blender at low speed. Mashing was carried out with a grist to water ratio of $1: 3$ at a temperature of $45^{\circ} \mathrm{C}$ for 15 minutes and $60^{\circ} \mathrm{C}$ for one hour along with commercial $\alpha$-amylose (Palkozyme, courtesy M/S maps - India Ltd. Ahmedabad). The enzyme concentrations of $0.1,0.5$ and 1 per cent were tested for saccharisfication of the substrate. The incubation temperature levels of $30^{\circ} \mathrm{C}, 50^{\circ} \mathrm{C}$ and $60^{\circ} \mathrm{C}$ and different incubation periods of 8,16 and $24 \mathrm{~h}$ were also used for standardizing the optimum activity of commercial enzymes. The best sorghum variety and the optimised parameters for malting and mashing were used for wort preparation. The wort obtained after double filtering the mash, was boiled for an hour. For flavouring, hops in the form of pellets (acid extracted, courtery: M/S U.B. Breweries, Mangalore) was added @ 40 ppm after 30 minutes of boiling. The $\mathrm{pH}$, total soluble solids (TSS), tannin content and reducing sugars were estimated.

Amylase activity was estimated by the method described by Bernfield (1955). Reducing sugars were determined by 3,5-dinitrosalicylic acid method (Miller, 1959). The $\mathrm{pH}$ meter of Analog model (Corion Research, USA) was used to record the $\mathrm{pH}$ of wort. Total soluble solids (TSS) was determined with the help of ERMA hand refractometer having range of 0$32^{\circ}$ Brix at $20^{\circ} \mathrm{C}$. Folin-Denis method was used for estimation of tannins (Schanderl, 1970). The experimental results were statistically analyzed as per Fisher's analysis of variance technique (Panse and Sukhatme, 1961).

\section{Results and Discussion}

The amylase activity and reducing sugars released in the grains soaked at different soaking period and germination period are 
presented in Table 1. Significantly high amylase activity (1213.23 $\mu \mathrm{g}$ of protein/15 $\mathrm{min} / \mathrm{g}$ sample) and reducing sugars (28.04 $\mathrm{mg} / \mathrm{g}$ ) was obtained on the third day of germination. Among the soaking period, $16 \mathrm{~h}$ of soaking recorded the highest amylase activity (1239.76 $\mu \mathrm{g}$ of protein $/ 15 \mathrm{~min} / \mathrm{g}$ sample) and reducing sugars (30.98 $\mathrm{mg} / \mathrm{g}$ ). Among the different varieties used, sweet sorghum 'SSV-84' recorded highest amylase (1266.10 $\mu \mathrm{g}$ of protein $/ 15 \mathrm{~min} / \mathrm{g}$ sample and reducing sugars $(31.51 \mathrm{mg} / \mathrm{g})$, while sweet sorghum SSV-74 showed the least amylase activity and reducing sugars. These results clearly indicate that the variety 'SSV-84' with a soaking period of $16 \mathrm{~h}$ and germination period of 3 days in optimum for malting. The difference in amylase activity and reducing sugars may be because of the soluble fraction of amylase enzyme that increases during germination upto certain extent releasing more sugars. Uvere et al., (2000) determined alpha amylase activity in one red and white varieties of sorghum, steeped in water for $18 \mathrm{~h}$ and germinated upto 5 days and found that $\alpha$ amylase activity peaked on third day of germination in white sorghum variety (550 $\mu / 100 \mathrm{~g})$.

The results of the effect of enzyme concentration, incubation temperature and incubation period of commercial $\alpha$-amylase on release of reducing sugars are presented in Table 2, 3 and 4. The grains treated with 1 per cent of commercial enzymes released maximum reducing sugars $(70.79 \mathrm{mg} / \mathrm{g})$
(Table 2). In case of incubation temperature, the highest reducing sugars was recorded at $70^{\circ} \mathrm{C}(68.52 \mathrm{mg} / \mathrm{g}$ (Table 3$)$ which did not show any significant difference with the reducing sugars obtained at $50^{\circ} \mathrm{C}(68.42 \mathrm{mg} / \mathrm{g})$ and were on par with each other (Table 3 ). Among the incubation periods, used for maximum hydrolysis of the substrate (Table 4 ), incubation period of 24 hours recorded high reducing sugars than other treatment (72.02 mg/g) (Table 4). Among the varieties, sweet sorghum SSV-84 recorded the highest reducing sugars in all the treatments tested for enzyme optimisation. The variation in reducing sugars among the varieties with commercial enzyme treatment could be due to the fact that the reaction of enzymes is based on the composition of the grains. High glucose content in sorghum malt wort was obtained by the addition of amyloglucosidase at a concentration of $0.59 \mathrm{~g} / \mathrm{L}$ of wort and a temperature of $55^{\circ} \mathrm{C}$ during mashing (PozoInsfran et al., 2004). All optimised parameters for malting and mashing were used for wort preparation. The $\mathrm{pH}$ of $5.20,7.55$ of $14.50^{\circ}$ Brix, tannin content of $13.15 \mathrm{mg} / 100 \mathrm{ml}$ and reducing sugars of $73.72 \mathrm{mg} / \mathrm{g}$ was recorded in the wort (Table 1A).

The present investigation clearly revealed that the grains of sweet sorghum variety 'SSV-84' soaked for $16 \mathrm{~h}$ and germinated for a period of 3 days gave the highest amylase activity and reducing sugars compared to other treatments, thus indicating its high potential as a malt source for brewing process.

Table.1A Chemical analysis of wort prepared from sweet sorghum variety (SSV-84) for beer production

\begin{tabular}{|l|c|}
\hline \multicolumn{1}{|c|}{ Parameters } & Values \\
\hline $\mathrm{pH}$ & 5.20 \\
\hline Total Soluble Solids (TSS) & $14.50^{\circ} \mathrm{Brix}$ \\
\hline Tannin content & $13.15 \mathrm{mg} / 100 \mathrm{ml}$ \\
\hline Reducing sugars & $73.72 \mathrm{mg} / \mathrm{g}$ \\
\hline
\end{tabular}




\section{Int.J.Curr.Microbiol.App.Sci (2018) 7(7): 651-658}

Table.1 Amylase activity and reducing sugars of 2 and 3 days germinated grains at different soaking time

\begin{tabular}{|c|c|c|c|c|c|c|c|c|c|c|c|c|c|c|c|c|}
\hline \multirow{3}{*}{ Varieties } & \multicolumn{8}{|c|}{ AMYLASE ACTIVITY ( $\mu \mathrm{g}$ of protein/15 min/g of sample) } & \multicolumn{8}{|c|}{ REDUCING SUGARS (mg/g) } \\
\hline & \multicolumn{4}{|c|}{2 days of germination } & \multicolumn{4}{|c|}{3 days of germination } & \multicolumn{4}{|c|}{2 days of germination } & \multicolumn{4}{|c|}{3 days of germination } \\
\hline & $8 \mathrm{~h}$ & $12 \mathrm{~h}$ & $16 \mathrm{~h}$ & Mean & $8 \mathrm{~h}$ & $12 \mathrm{~h}$ & $16 \mathrm{~h}$ & Mean & $8 \mathrm{~h}$ & $12 \mathrm{~h}$ & $16 \mathrm{~h}$ & Mean & $8 \mathrm{~h}$ & $12 \mathrm{~h}$ & $16 \mathrm{~h}$ & Mean \\
\hline SSV-74 & 1125.03 & 1163.36 & 1200.66 & 1163.02 & 1168.40 & 1186.30 & 1234.00 & 1196.23 & 21.70 & 24.45 & 25.55 & 23.90 & 23.26 & 25.55 & 28.43 & 25.75 \\
\hline SSV-84 & 1225.83 & 1240.66 & 1260.43 & 1242.31 & 1240.10 & 1251.26 & 1266.10 & 1252.48 & 25.38 & 30.60 & 31.51 & 29.16 & 28.80 & 31.46 & 33.85 & 31.37 \\
\hline SSV-108 & 1154.20 & 1177.40 & 1212.80 & 1181.46 & 1156.86 & 1182.76 & 1219.70 & 1186.44 & 23.10 & 25.16 & 27.98 & 25.41 & 23.83 & 27.03 & 29.70 & 26.85 \\
\hline DSV-2 & 1195.16 & 1206.46 & 1235.60 & 1212.41 & 1202.40 & 1211.63 & 1239.26 & 1217.76 & 23.13 & 27.35 & 30.73 & 27.07 & 24.16 & 28.48 & 31.96 & 28.20 \\
\hline Mean & 1175.05 & 1196.97 & 1227.37 & 1199.80 & 1191.94 & 1207.99 & 1239.76 & 1213.23 & 23.32 & 26.89 & 28.94 & 26.38 & 25.01 & 28.13 & 30.98 & 28.04 \\
\hline Source & \multicolumn{4}{|c|}{ SEm \pm} & \multicolumn{4}{|c|}{$\mathrm{CD}$ at $1 \%$} & \multicolumn{4}{|c|}{ SEm \pm} & \multicolumn{4}{|c|}{$\mathrm{CD}$ at $1 \%$} \\
\hline $\begin{array}{l}\text { Varieties } \\
\text { (V) }\end{array}$ & \multicolumn{4}{|c|}{6.059} & \multicolumn{4}{|c|}{22.989} & \multicolumn{4}{|c|}{0.274} & \multicolumn{4}{|c|}{1.039} \\
\hline $\begin{array}{l}\text { Soaking } \\
\text { time }(\mathrm{S})\end{array}$ & \multicolumn{4}{|c|}{5.247} & \multicolumn{4}{|c|}{19.908} & \multicolumn{4}{|c|}{0.237} & \multicolumn{4}{|c|}{0.899} \\
\hline $\begin{array}{l}\text { Germination } \\
\text { period }(G)\end{array}$ & \multicolumn{4}{|c|}{4.284} & \multicolumn{4}{|c|}{16.254} & \multicolumn{4}{|c|}{0.194} & \multicolumn{4}{|c|}{0.736} \\
\hline VS & \multicolumn{4}{|c|}{10.495} & \multicolumn{4}{|c|}{ NS } & \multicolumn{4}{|c|}{0.475} & \multicolumn{4}{|c|}{1.802} \\
\hline VG & \multicolumn{4}{|c|}{8.569} & \multicolumn{4}{|c|}{ NS } & \multicolumn{4}{|c|}{0.388} & \multicolumn{4}{|c|}{ NS } \\
\hline SG & \multicolumn{4}{|c|}{7.421} & \multicolumn{4}{|c|}{ NS } & & 0.3 & & & & $\mathrm{~N}$ & & \\
\hline VSG & & 14.8 & 343 & & & $\mathrm{~N}$ & S & & & 0.6 & & & & $\mathrm{~N}$ & & \\
\hline
\end{tabular}

NS - Non significant 
Int.J.Curr.Microbiol.App.Sci (2018) 7(7): 651-658

Table.2 Optimization of enzyme concentration for saccharification by commercial $\alpha$-amylase

\begin{tabular}{|c|c|c|c|c|c|c|}
\hline \multirow{3}{*}{$\begin{array}{l}\text { Sl. } \\
\text { No. }\end{array}$} & \multirow{3}{*}{ Varieties } & \multicolumn{5}{|c|}{ Reducing sugars (mg/g) } \\
\hline & & \multicolumn{5}{|c|}{ Concentration of $\alpha$-amylase (\%) } \\
\hline & & 0.1 & 0.5 & 1.0 & Mean & $\begin{array}{l}\text { Control (without } \\
\text { amylase enzyme) }\end{array}$ \\
\hline 1. & SSV-74 & 48.00 & 57.74 & 65.92 & 49.77 & 27.44 \\
\hline 2. & SSV-84 & 63.32 & 67.32 & 73.42 & 59.06 & 32.20 \\
\hline 3. & SSV-108 & 49.36 & 62.21 & 71.64 & 53.33 & 30.14 \\
\hline \multirow[t]{6}{*}{4.} & DSV-2 & 50.18 & 65.60 & 72.18 & 54.67 & 30.71 \\
\hline & Mean & 52.71 & 63.22 & 70.79 & 54.21 & 30.12 \\
\hline & Source & \multicolumn{2}{|c|}{ S.Em \pm} & \multicolumn{2}{|c|}{$\mathrm{CD}$ at $1 \%$} & \\
\hline & Varieties (A) & \multicolumn{2}{|c|}{0.435} & \multicolumn{2}{|c|}{1.771} & \\
\hline & Concentration (B) & \multicolumn{2}{|c|}{0.376} & \multicolumn{2}{|c|}{1.533} & \\
\hline & Interaction (A x B) & \multicolumn{2}{|c|}{0.753} & \multicolumn{2}{|c|}{3.067} & \\
\hline
\end{tabular}


Table.3 Optimization of incubation temperature for commercial $\alpha$-amylase

\begin{tabular}{|c|c|c|c|c|c|c|}
\hline \multirow{3}{*}{$\begin{array}{l}\text { Sl. } \\
\text { No. }\end{array}$} & \multirow{3}{*}{ Varieties } & \multicolumn{5}{|c|}{ Reducing sugars (mg/g) } \\
\hline & & \multicolumn{5}{|c|}{ Incubation temperature $\left({ }^{\circ} \mathrm{C}\right)$} \\
\hline & & 30 & 50 & 70 & Mean & $\begin{array}{l}\text { Control (without } \\
\text { amylase enzyme at } \\
\text { ambient } \\
\text { temperature) }\end{array}$ \\
\hline 1. & SSV-74 & 56.64 & 63.74 & 63.81 & 53.01 & 27.86 \\
\hline 2. & SSV-84 & 64.14 & 72.35 & 72.38 & 60.45 & 32.92 \\
\hline 3. & SSV-108 & 59.32 & 67.10 & 67.17 & 55.74 & 29.36 \\
\hline \multirow[t]{6}{*}{4.} & DSV-2 & 62.73 & 70.51 & 70.71 & 58.60 & 30.46 \\
\hline & Mean & 60.70 & 68.42 & 68.52 & 56.95 & 30.15 \\
\hline & Source & \multicolumn{2}{|c|}{ S.Em \pm} & \multicolumn{2}{|c|}{$\mathrm{CD}$ at $1 \%$} & \\
\hline & Varieties (A) & \multicolumn{2}{|c|}{0.572} & \multicolumn{2}{|c|}{2.331} & \\
\hline & Concentration (B) & \multicolumn{2}{|c|}{0.495} & \multicolumn{2}{|c|}{2.018} & \\
\hline & Interaction (A x B) & \multicolumn{2}{|c|}{0.991} & \multicolumn{2}{|c|}{ NS } & \\
\hline
\end{tabular}


Int.J.Curr.Microbiol.App.Sci (2018) 7(7): $651-658$

Table.4 Optimization of incubation period for commercial $\alpha$-amylase

\begin{tabular}{|c|c|c|c|c|c|c|}
\hline \multirow{3}{*}{$\begin{array}{l}\text { Sl. } \\
\text { No. }\end{array}$} & \multirow{3}{*}{ Varieties } & \multicolumn{5}{|c|}{ Reducing sugars (mg/g) } \\
\hline & & \multicolumn{5}{|c|}{ Incubation period $(\mathrm{h})$} \\
\hline & & 8 & 16 & 24 & Mean & $\begin{array}{l}\text { Control (without } \\
\text { amylase enzyme) }\end{array}$ \\
\hline 1. & SSV-74 & 51.18 & 55.29 & 66.62 & 50.30 & 28.10 \\
\hline 2. & SSV-84 & 60.38 & 65.04 & 78.72 & 59.15 & 32.47 \\
\hline 3. & SSV-108 & 50.06 & 57.82 & 69.31 & 51.73 & 29.74 \\
\hline \multirow[t]{6}{*}{4.} & DSV-2 & 56.26 & 61.17 & 73.43 & 55.71 & 31.99 \\
\hline & Mean & 54.47 & 59.83 & 72.023 & 54.22 & 30.58 \\
\hline & Source & \multicolumn{2}{|c|}{ S.Em \pm} & \multicolumn{2}{|c|}{$\mathrm{CD}$ at $1 \%$} & \\
\hline & Varieties (A) & \multicolumn{2}{|c|}{0.276} & \multicolumn{2}{|c|}{1.126} & \\
\hline & Concentration (B) & \multicolumn{2}{|c|}{0.239} & \multicolumn{2}{|c|}{0.975} & \\
\hline & Interaction $(\mathrm{A} \times \mathrm{B})$ & \multicolumn{2}{|c|}{0.479} & \multicolumn{2}{|c|}{1.951} & \\
\hline
\end{tabular}




\section{References}

Almodares A, Sepahi A, Dalilotojjary H. Ghyami R, 1994. Effect of phonological stages and carbohydrate contents of sweet sorghum cultivars. Ann. Pl. Physio., 8: 42-48.

Bernfield P, 1955. In: Methods of Ehzymdogy, Academic Press, New York, 1: 149.

Bhise VJ, Chavan JK, Kadam SS, 1988. Effect of malting on proximate composition and in vitro protein and starch digestibilities of grain sorghum. J. Food Sci. Tech., 25: 327-329.

Miller GL, 1959. Use of dinitrosalicylic acid reagent for determination of reducing sugars. Ann. Chem., 31: 426-428.

Panse YG, Sukhatme, 1961, Statistical methods for agricultural workers, ICAR, New Delhi, p.381.

Pozo-Infran DD, Drias-Kegb D, FernandezBrenes C. Soldivar SOS, 2004, Effect of amyloglucosidase on wort composition and fermentable carbohydrate depletion in sorghum layer beers. J. Ins. Bre., 110: 124-132.

Rothschild D, 1972. Push button beer at Congella, Food Industries of South Africa, 24(11): 19.

Satyanarayana R, Narasimham VVL, 1975. Adjuncts in brewing. J. Food Sci. Tech., 12: 217-220.

Schanderl SH, 1970. In: Methods in Food Analysis, Academic Press, New York, 709.

Seetharama N, Dayakar RB, Ratnavathi CV, Shahid PM, Mathew B, Bharathkumar KA, 2002. Sorghum as a raw material for alcohol production. Presented at the seminar on current development in alcohol industry organized by Distiller's Association of Maharashtra, 25 August 2002, Sahar, Mumbai, India.

Uvere PO, Adenyu OD, Mordi C, 2000. The effect of germination and kilning on the cyanogemic potential, amylose and alcohol levels of sorghum malts used for Burukutu production. J. Sci. Food and Agri., 80: 352-358.

\section{How to cite this article:}

Seema Mesta, G.S. Geeta and Ashwini, M. 2018. Optimization of Malting and Mashing Conditions of Sweet Sorghum Grains as a Brewing Source. Int.J.Curr.Microbiol.App.Sci. 7(07): 651-658. doi: https://doi.org/10.20546/ijcmas.2018.707.079 